\title{
Mengkaji Kesehatan Masyarakat Daerah “Urban” Jika Dilihat Dari Konteks Pemuda
}

\author{
Robist Hidayat $^{1}$ \\ ${ }^{1}$ Program Studi Ekonomi Perbankan Islam, Universitas Muhammadiyah Yogyakarta, Jalan Brawijaya , \\ Kasihan, Bantul,Yogyakarta, Indonesia
}

Penulis untuk Korespondensi/E-mail: robisth96@gmail.com

\begin{abstract}
Abstrak - Kesehatan merupakan faktor penting kehidupan, tak terkecuali kaum urban di perkotaan besar di Indonesia, banyak permasalahan terjadi, prasarana idak memadai, kehidupan yang buruk menimbulkan masalah serius baik sekarang dan masa yang akan datang. Salah satu bagian kaum urban adalah pemuda, merupakan kaum di antara anak-anak dan juga dewasa. Sehingga di harapkan memiliki solusi untuk menghadapi permsaalahan tersebut. Penelitian ini bertujuan untuk melihat bagaiman peranan pemuda mengkaji permasalahan yang terjadi sehingga bisa mendapatkan solusi sederhana untuk mengatasi permasalahan kaum urban diperkotaan besar. Adapun metode yang digunakan penulis yakni metode deskriptif, mengkaji serta menganalisis literasi-literasi yang ada dan menyimpulkan menjadi sebuah solusi dari permasalahan yang penulis ungkapkan. Adapun hasil dari penelitian ini ,bahwa permasalahan kaum urban terletak pada tidak adanya program yang jelas serta terperinci secara baik, baik itu dari pemerintah daerah maupun pusat. Sehingga hal ini menjadi permasalahan bersama bukan salah satu pihak semata. Adapun yang bisa pemuda berikan solusi: yakni mencangkup program dan juga kebijakan, program yang di berikan yakni terdiri 3 tahap, yaitu: jangka pendek, menengah dan panjang. Adapun alasannya yaitu program tersebut di terapkan sesuai dengan kebutuhan kaum urban serta kebijakan yang merupakan wewenang dari pemerintah. Bisa disimpulkan, pemuda memiliki peranan penting dalam mengkaji ataupun memberikan solusi yang terbaik untuk kesehatan kaum urban.
\end{abstract}

Abstract - Health is an important factor of life, including urban in large urban areas in Indonesia, many problems occur, infrastructure is inadequate, a bad life causes serious problems both now and in the future. One part of the urban community is youth, is a family among children and also adults. So that it is expected to have a solution to deal with these problems. This study aims to see how the role of youth examines the problems that occur so that they can get a simple solution to overcome urban problems in large cities. The method used by the author is descriptive method, reviewing and analyzing existing literacy and concluding to be a solution to the problems that the writer reveals. The results of this study, that the problem of urbanites lies in the absence of a clear and well-detailed program, both from the local and central government. So this matter becomes a common problem, not only one part. As for what the youth can provide a solution: namely covering the program and also the policy, the program provided is consisting of 3 stages, namely: short, medium and long term. The reason is that the program is implemented in accordance with the needs of the urbanites and policies that are the authority of the government. It can be concluded, youth have an important role in assessing or providing the best solution for urban health.

Keywords - Role of Youth, Urban Community Health, Problems, Programs

\section{PENDAHULUAN}

$\mathrm{K}$ esehatan merupakan bagian terpenting dari kesejahteraan masyarakat. Dimana Kesehatan ini merupakan salah satu hak hakiki manusia, disamping sandang, pangan dan papan. Perkembangan pelayanan kesehatan pada masa ini, mengakibatkan memahami etika kesehatan merupakan tuntunan yang dipandang sangat perlu bahkan bersifat wajib.

Konsep dasar hukum kesehatan mempunyai ciri istimewa yaitu beraspek: (1) Hak Asasi Manusia (HAM) yang merupakan hak setiap individu, (2) Kesepakatan internasional, merupakan keharusan karena setiap negara harus saling membantu dan menghagai (3) Legal baik pada level nasional 
maupun internasional, (4) Iptek yang termasuk tenaga kesehatan professional. Secara normatif menurut Undang-undang Kesehatan Nomor 23 Tahun $1992^{1}$, harus mengutamakan pelayanan kesehatan: 1. Menjadi tanggung jawab pemerintah dan swasta dengan kemitraan kepada pihak masyarakat. 2. Semata-mata tidak mencari keuntungan. Dua batasan nilai norma hukum tersebut perlu ditaati agar tidak mengakibatkan reaksi masyarakat dan tumbuhnya konflik dengan gugatan/tuntutan hukum. Apalagi saat ini pertumbuhan kota sangat pesat bahkan terlampau cepat berkembangnya. Namun hal itu tidak dilandasi oleh kesehatan masyarakat didalamnya, seperti masih banyak rumah yang tidak memiliki ventilasi udara yang baik, drainase yang buruk, intensitas kelembapan yang tinggi, dan masih banyak lagi indikator yang dapat menggangu kesehatan. Dari banyaknya masyarakat yang menjadi penghuni perkotaan ada kaum pemuda yang menjadi penghuni tersebut. Baik itu yang bekerja, menuntut ilmu maupun menjadi kaum urbanisasi yang tidak memiliki keterampilan apapun(pengangguran). Oleh karen itu sebagai pemuda sudah seharusnya mendalami sebab akibat tersebut, masa depan bangsa tergantung apa yang pemuda perbuat masa kini dan masa sekarang terutama dalam hal kesehatan. Karena dengan berperan pemuda dalam hal kesehtan kaum urban bisa didapati solusi cerdas sesuai dengan kebutuhan kaum urban. Pertumbuhan penduduk dalam suatu wilayah perkotaan selalu diikuti oleh peningkatan kebutuhan ruang. Kota sebagai perwujudan geografis selalu mengalami perubahan dari waktu ke waktu. Dua faktor utama yang sangat berperan adalah faktor penduduk (demografis) dan aspekaspek kependudukan (Yunus, 1987). Dari segi demografi yang paling penting adalah segi kuantitas. Aspek kependudukan seperti aspek politik, sosial, ekonomi, dan teknologi juga selalu mengalami perubahan. Kuantitas dan kualitas kegiatannya selalu meningkat sejalan dengan pertambahan penduduk perkotaan, sehingga ruang sebagai wadah kegiatan tersebut selalu meningkat sejalan dengan pertambahan penduduk perkotaan, sehingga ruang sebagai wadah kegiatan tersebut selalu mengalami peningkatan.[1]

Kawasan perkotaan yang sering disebut dengan kawasan urban adalah sebuah wilayah yang mempunyai beberapa kegiatan utama bukan dalam hal pertanian melainkan sebagai kawasan permukiman perkotaan, pemusatan dan distribusi pelayanan jasa pemerintahan, pelayanan sosial, dan kegiatan ekonomi. Tidak dipungkiri lagi bahwa, saat ini pemerintah sedang giat-giatnya melaksanakan pembangunan demi terciptanya masyarakat dengan tingkat kesejahteraan yang rata.
Kita hidup dalam era pembangunan. Pembangunan pada hakikatnya adalah perubahan, yaitu mengubah keadaan yang dianggap kurang baik menjadi keadaan yang lebih baik. Keseimbangan lingkungan diubah ke keseimbangan yang baru.[2]

Namun hal yang terjadi tidaklah sebanding dengan pesatnya pembangunan demi kebutuhan, banyak terjadinya penyalahgunaan pembangunan tanpa melihat dampak negatif atau positif bagi lingkungan disekitar. Oleh karena hal itulah rumusan masalah yang dapat diketahui dari latar belakang tersebut yakni bagaimana sikap dan cara pemuda untuk mengkaji secara sederhana tentang masyarakat di daerah urban mengenai kesehtan masyarkat di daerah tersebut. Adapun tujuan dari penelitian studi pustaka ini adalah bagaimanakah konsep atau cara yang bisa pemuda lakukan mengenai kesehatan kaum urban .

\section{METODE}

Dalam penelitian sederhana ini menggunakan metode diskriptif, yaitu penulisan yang memusatkan diri pada pemecahan masalah yang aktual, data yang dikumpulkan disusun, dijelaskan dan dianalisis (Suracmad, 1980). Pembahasan masalah dengan menggunakan studi pustaka sebagai sumber informasi. Sehingga informasi yang sudah di dapatkan tersebut bisa diolah dan mendapatkan informasi sesuia dengan konteks penelitian.

\section{HASIL TINJAUAN PUSTAKA dan DISKUSI}

Adapun yang dapat dihasilkan dari beberapa literasi dan diskusi terbuka, dapat dibagi menjadi beberapa bagian yakni :

\section{A. Kesehatan Masyarakat Saat Ini.}

Situasi masyarakat miskin perkotaan perlu mendapatkan perhatian segera. Di daerah-daerah kumuh perkotaan, sanitasi yang tidak memadai, praktek kebersihan yang buruk, kepadatan penduduk yang berlebihan, serta air yang terkontaminasi secara sekaligus dapat menciptakan kondisi yang tidak sehat. Penyakit-penyakit terkait dengan ini meliputi disentri, kolera dan penyakit diare lainnya, tipus, hepatitis, leptospirosis, malaria, demam berdarah, kudis, penyakit pernapasan kronis dan infeksi parasit usus. Selain itu, keluarga dengan ekonomi menengah kebawah yang kurang berpendidikan cenderung melakukan praktekpraktek kebersihan yang buruk, yang berkontribusi terhadap penyebaran penyakit dan peningkatan 
resiko kematian anak. Studi tentang "mega-kota” Jakarta (yang disebut Jabotabek), Bandung dan Surabaya pada tahun 2000 menunjukkan bahwa penduduk miskin yang tinggal di daerah pinggiran kota Jakarta kurang berpendidikan dibandingkan warga Jakarta sendiri, dan memiliki tingkat tamat Sekolah Menengah Pertama hanya seperempat dari mereka yang tinggal di pusat kota. Studi yang sama menghitung angka kematian anak sampai lima kali lebih tinggi di kecamatan-kecamatan miskin di pinggiran kota Jabotabek[2].

Studi tentang mega kota Jakarta adalah salah satu contoh kasus kaum urban di perkotaan besar di Indonesia, tidak hanya orang dengan ekonomi menengah keatas saja yang mendiami kota metropolitan, melainkan juga kaum pendatang yang tidak memiliki keterampilan apapun ikut mendiami metropolitan. Pola dan kecenderungan pada dekadedekade sebelumnya, Indonesia telah menunjukkan kemajuan signifikan dalam meningkatkan akses terhadap persediaan air bersih dan pelayanan sanitasi[3].

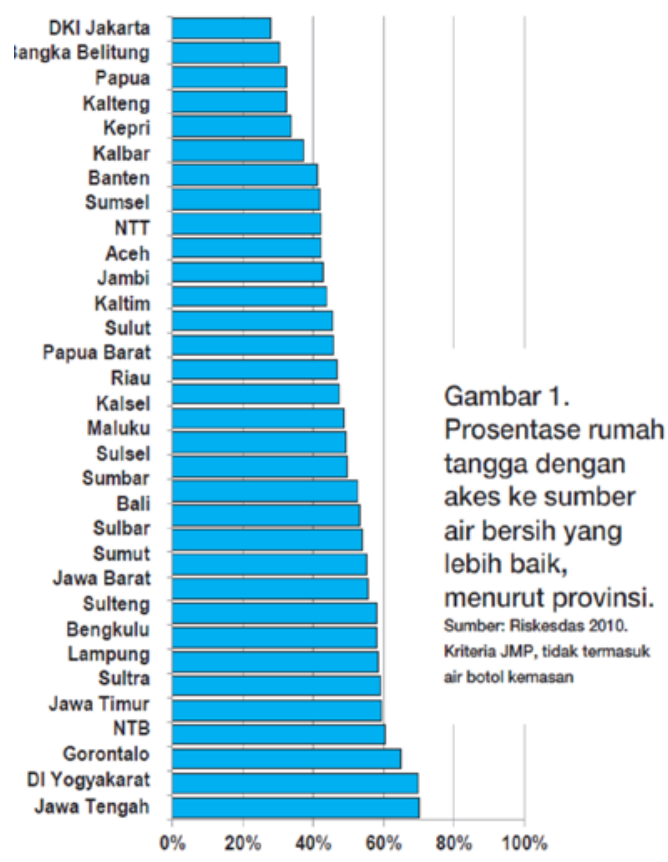

Sumber: Riskesdas 2010. Kriteria JMP, tidak termasuk air botol

Gambar 1. Prosentase Rumah Tangga dengan Akses ke Sumber Air Bersih yang Lebih Baik, Menurut Provinsi

Berdasarkan Gambar 1, kota DKI Jakarta merupakan kota yang memiliki akses ke sumber air bersih paling buruk. Hal ini membuktikan kota besar dengan hutan beton mempunyai komponen yang buruk untuk kesehatan. Air adalah sumber dari Kesehatan masyarakat. Namun hal ini belumlah secara defacto dejure bahwa sangat buruk secara riset belum dilakukan dengan baik.

\section{B. Sistem kesehatan di Indonesia dan cakupannya di daerah urban [4]}

WHO mendefinisikan sistem kesehatan sebagai seluruh kegiatan yang memiliki tujuan untuk meningkatkan dan memelihara kesehatan. Merujuk definisi yang diberikan oleh WHO maka komponen kesehatan meliputi pelayanan kesehatan formal dan pengoabatan tradisional. Aktivitas yang merupakan sistem dari kesehatan tidak hanya kegiatan yang umum dilakukan seperti promosi kesehatan, pencegahan penyakit, peningkatan keamanan lingkungan dan jalan raya, pendidikan yang berhubungan dengan kesehatan merupakan bagian dari sistem.

Sistem kesehatan paling tidak mempunyai 4 fungsi pokok yaitu: Pelayanan kesehatan, pembiayaan kesehatan, penyediaan sumberdaya dan stewardship/regulator. Fungsi-fungsi tersebut akan direpresentasikan dalam bentuk sub-subsistem dalam sistem kesehatan, dikembangkan sesuai kebutuhan.

Sama halnya dengan kebutuhan pangan, kesehetan juga merupakan kebutuhan pokok yang menjadi hak setiap warga negara, sehingga pemerintah wajib menyediakan sistem pelayanan kesehatan yang baik untuk warganya. Jika dibandingkan penduduk golongan ekonomi menengah ke atas, golangan ekonomi menengah ke bawah yang tinggal di pinggiran perkotaan mengeluarkan biaya yang lebih besar dari pendapatan mereka untuk air yang berkualitas lebih buruk. Misalnya, sistem pipa kota Jakarta hanya mencakup sebagian kecil penduduk, karena perluasan pelayanan tidak dapat mengimbangi perkembangan penduduk di daerah perkotaan. Penduduk lainnya tergantung pada berbagai sumber lain, termasuk sumur dangkal, penjual air keliling dan jaringan privat yang terhubung dengan sumur yang dalam. Banyak dari sumber-sumber alternatif ini memerlukan biaya yang lebih besar per satuan volume daripada pasokan air ledeng dan sering digunakan oleh masyarakat miskin

Permasalahan susahnya akses air bersih merupakan salah satu hal yang mengakibatkan permasalahn kesehatan di daerah urban seperti penyakit kulit dan diare. Selain susahnya akses air bersih, keadaan air yang kotor (dangkal) serta kurang jernih, air yang 
ada seperti berwarna kehitaman dan kekuningan serta berbau mengakibatkan gangguan kesehatan bagi penduduk di sekitar wilayah tersebut. Kondisi air yang demikian tidak hanya berdampak pada penduduk sekitar namun juga berdampak pada lingkungan.

Keadaan sistem drainase yang buruk atau bahkan tidak ada, mengakibatkan banyak genangan air disana-sini bila terjadinya hujan, kalaupun ada tidak sesuai dengan prosedur dan asal jadi. Pembuatan sanitasi yang sangat tidak bagus, dimana tata letaknya berdekatan dengan bangunan, dimana dalam aturannya lumayan jauh dengan bangunan. Namun hal yang terjadi karena banyaknya gedung bertingkat yang ada dengan kepadatan yang luar biasa mengakibatkan tempat pembuangannya sangat dekat bahkan diarea bangunan, sungguh lokasi yang tidak sehat.

\section{Peranan Pemuda akan kesehatan masyarakat di daerah urban}

Pemuda merupakan konsep-konsep yang selalu dikaitkan dengan masalah "Nilai" hal ini sering lebih merupakan pengertian ideologis dan cultural dari pada pengertian ilmiah, misalnya "Pemuda harapan bangsa" dan "pemuda pemilik masa depan" dan lain sebagainya yang kesemuanya itu merupakan beban moral bagi pemuda untuk memberikan konstribusi pada masa depan masyarakat bangsa Indonesia. Tetapi dilain pihak pemuda menghadapi persoalan-persoalan yang rumit seperti narkoba, kenakalan remaja, dan terbatasnya lapangan kerja. ${ }^{5}$

Di atas telah dikemukakan bahwa pemuda adalah generasi muda merupakan istilah demografis dan sosiologis dalam konteks tertentu. Oleh karena itu, generasi muda perlu mendapatkan perhatian khusus sehingga dapat berperan aktif dalam perkembangan bangsa. Saat ini yang perlu dicari adalah peranan pemuda yang seperti apakah yang dibutuhkan sehingga bisa digunakan dalam membantu permasalahn yang ada di daerah urban. Secara teoritis mungkin banyak sekali progam pemerintah yang mendukung dan membuat program kesehatan masyarakat.

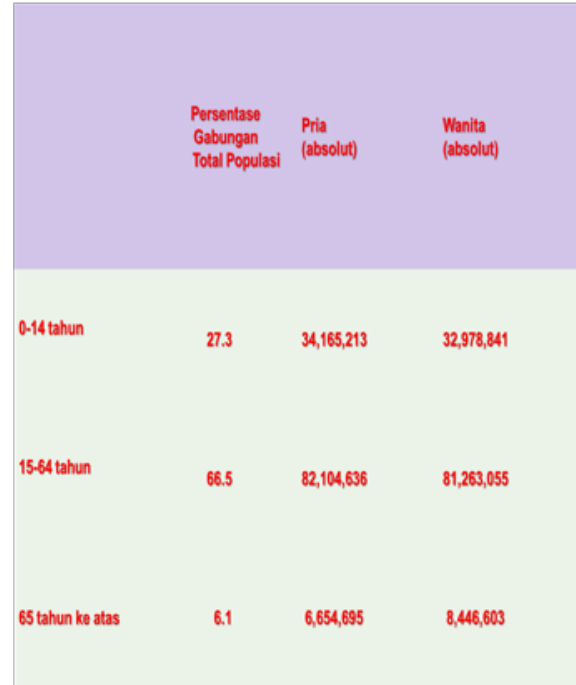

Sumber: CIA World Factbook menunjukkan bahwa CIA World Factbook presentase terbanyak, sehingga mempunya po presentase terbanyak, sehingga mempunyai potens untuk membangun bangsa ini. Dengan hal itulah kita harus membantu pemerintah untuk membangun negeri ini karena ini adalah kewajiban kita bersama.

\section{PELUANG DAN SOLUSI}

\section{Peluang}

Sebagai negara yang besar, Indonesia mempunyai berbagai peluang untuk mencapai kesehatan masyarkat secara berkelanjutan, antara lain:

1. Indonesia memiliki sumber daya yang mumpungi seperti dalam segi kesehatan

2. Perkembangan teknologi yang pesat dalam berbagai aspek; dalam hal ini adalah dalam bidang kesehatan sehingga bisa membantu masyrakat urban yang rawan akan kesehatannya

3. Semangat anak muda yang perlu di apresiasi karena dengan idealisme serta kecakapannya mampu bersaing dengan yang lain dalam kesehatan

Adapun solusi yang di tawarkan :

\section{Program [7]}

Dengan memperhatikan pedoman dan ketentuan hukum, serta tujuan dan strategi untuk mewujudkan indonesia sehat, maka kebijakan dan program yang akan ditempuh dikelompokkan dalam 1) Program jangka pendek (sampai dengan 5 tahun).

2) Program jangka menengah (5-10 tahun ) dan 3) Program jangka panjang (> 10 tahun)

\section{A. Program Jangka Pendek.}

Program jangka pendek ditujukan untuk peningkatan kapasitas kesehatan masyarakat 
nasional dengan menggunakan sumberdaya yang telah ada dan teknologi yang telah teruji. Komponen utama program ini adalah

Peningkatan pelayanan kesehatan, meliputi:

(1) Pelayanan kesehatan penduduk miskin di puskesmas dan jaringannya. Pelayanan ini sangat dibutuhkan karena masyarakat urban sangat rawan stress.

(2) Pelayanan kesehatan bagi penduduk miskin di kelas III rumah sakit.

(3) Peningkatan pelayanan kesehatan rujukan terutama untuk penanganan penyakit menular dan berpotensi wabah, pelayanan kesehatan ibu dan anak, gizi buruk dan pelayanan Unit Gawat Darurat.

\section{B. Program Jangka Menengah (5-10 tahun).}

Perlindungan sosial, meliputi kegiatan prioritas sebagai berikut:

Peningkatan perlindungan kepada keluarga miskin, termasuk perempuan dan anak, meliputi:

(1) Jaminan penyediaan pelayanan KB dan alat kontrasepsi bagi keluarga miskin;

(2) Peningkatan akses informasi dan pelayanan ketahanan keluarga serta fasilitasi pemberdayaan keluarga;

(3) Fasilitasi pembentukan Pusat Pelayanan Terpadu Pemberdayaan Perempuan (P2TP2).

\section{Program Jangka Panjang (> 10 tahun)}

Perbaikan keadaan lingkungan hidup disekitar masyarkat di sekitar perkotaan ataupun kaum urban, mendidik masyarakat untuk lebih mengerti tentang cara-cara hidup sehat ,serta menignkatakan status gizi masyarakat[6]

\section{Edukasi}

Hal pertama yang mesti dilakukan oleh pemerintah adalah edukasi kepada masyarkat bahwa kesehatan adalah suatu kebutuhan yang penting agar bisa tumbuh berkembang, namun disini mengedukasi dengan cara tidak hanya mengandalkan program program kesehatan saja melainkan langsung ke masyarakat.

\section{Penyuluhan dan praktikum}

Ini adalah hal yang mesti dilakukan oleh pemerintah yakni penyuluhan dan praktikum ke pada masyarakat, dimana melakukan penyuluhan kepada masyarakat untuk meningkatkan kesadaran kesehatan masing-masing.

\section{Bantuan dana}

Bantuan dana merupakan hal yang wajib dilakukan pemerintah. Dalam hal ini, dana digunakan untuk menignkatkan kaulitas kesehatan masyarakat. Misalnya: digunakan untuk pembuatan rumah atau tempat tinggal yang layak serta sehat, MCK (mandi cuci kakus) yang layak dan masih banyak lagi penunjang kesehatan yang dibutuhkan.

\section{Evaluasi}

Evaluasi adalah langkah terakhir yang dilakukan oleh pemerintah yakni melihat sejauh mana program yang di berikan ke lapangan untuk masyarakat, untuk mengetahui kesalahan dan kebenaran program itu agar tidak menjadi program yang gagal dan hanya menghabiskan dana yang besar saja.

\section{Kebijakan dan Strategi Menuju Indonesia Lebih Sehat dan Bergizi}

1. Pemantapan ketersediaan kesehatan masyarakat perkotaan berbasis kemandirian;

2. Peningkatan kemudahan dan kemampuan mengakses kesehtan ;

3. Peningkatan kuantitas dan kualitas konsumsi pangan menuju gizi seimbang;

4. Peningkatan status gizi masyarakat;

5. Peningkatan mutu dan keamanan pangan.

Bagaimana dengan kontekstualnya dengan MEA akan program yang sudah diuraikan diatas. Menurut saya sangat bisa membaur bahkan suatu solusi untuk menghadapi MEA. Karena dengan adanya program yang jelas dari pemerintah ketahan pangan indonesi tidak akan tergoyah walaupun MEA sudah terwujud, karena kualitas pangan dalam negeri tidak kalah bersaing dengan pangan di luar negeri dan mencukupi kebutuhan masyarakat Indonesia.

\section{KESIMPULAN}

Berdasarkan hasil kajian pustaka dan penyimpulan beberapa literasi dapat dikatakan secara kontektual bahwa kesehatan masyarakat perkotaan (urban) merupakan hal yang mesti disegerakan dilaksanakan karena hidup di kota lebih berat dari pada hidup di pedesaan, banyak sekali faktor yang mempengaruhi kesehatan di perkotaan contohnya strees, polutan dan lainnya. Di sinilah kaum pemuda bisa berperan penting dalam meningkatkan kesehatan masyarakat urban. Hal ini bisa dilihat dari segi program maupun cara alternatif yang bisa disegerakan dan bisa didukung oleh pemerintah baik yang di daerah maupun yang di pusat. Karena program-program yang di rencanakan dan di bentuk oleh kaum pemuda tidaklah bisa berhasil apabilah kuranngya dukungan pemerintah. Disini bisa 
dikatakan bahwa pemuda itu dapat berperan dalam hal mengkaji ataupun perencanaan program untuk kesehatan kaum urban. Dimana program tersebut, dikategorikan dalam beberapa tahapan yakni program jangka pendek dimana program ini di rancang untuk sumber daya manusia ataupun yang sudah ada dikembangkan dan diperbaiki sehingga bisa berfungsi dengan baik. Kemudian program jangka menengah, dimana program ini di susun untuk prioritas setelah jangka pendek sudah teratasi dan yang terakhir program jangka panjang yang disusun untuk mencapai kesejahteraan ke depannya sehingga bisa dilaksanakan pada masa depan dengan melihat kerberhasilan program-program sebelumnya. Selain program yang dibuat, hal utama yang perlu diperhatikan adalah kebijakan dari pemerintah, karena program akan berjalan apabila pemerintah mempunyai kebijakan yang mendukung. Intinya adalah pemuda bukanlah beban sebuah negara, melainkan prioritas utama yang mesti didukung oleh pemerintah, apalagi dalam hal menjalankan program dan kebijakan untuk kesehatan kaum urban. Sehingga, pemuda dapat mengetahui secara baik bagaimana mengatasi permasalahan di dalam ruang lingkup urban di wilayah perkotaan.

\section{UCAPAN TERIMA KASIH}

Saya mengucapkan terima kasih kepada temanteman yang sudah mau berdiskusi dan mensupport saya agar bisa tetap semangat dalam penyusunan paper ini menginggat papers ini tidak ada sangkut pautnya dengan background pendidikan saya di perkuliahan, namun dengan support dan semangat yang ada akhirnya bisa terwujud paper ini walaupun tidak seprofesional yang lain namun ini adalah bukti bahwa dimana ada kesempatan dan kemauan maka ada jalan.

\section{DAFTAR PUSTAKA}

[1] Suripin, Sistem Drainase Perkotaan yang Berkelanjutan. Yogyakarta: Penerbit Andi, 2004.

[2] Giyarsih, Sri Rum. Jurnal Gejala Urban Sprawl Sebagai Pemicu Proses Densifikasi Permukiman Di Daerah Pinggiran Kota (Urban Fringe Area) Kasus Pinggiran Kota Yogyakarta. Yogyakarta : Universitas Gajah Mada.

[3] Jurnal ringkasan kajian, UNICEF INDONESIA, terbit tahun 2012.

[4] Ibid.

[5] R. Hidayat Terjemahan “"'Realization Asean Economic Community (Aec)” And How The Role Of Youth In A Success" Faculty Of Studies Islamic Economic \& Islamic Banking Muhammadiyah University Of Yogyakarta, To Presentation: Asean Youth Gathering (Aygath) International Relations 2016 Islamic University Of Indonesia.

[6] F.Aruna, Ppt Kesehtan Masyarkat, Pendidikan Kesehatan Dan Rekreasi Fakultas Ilmu Keolahragaan Universitas Negeri Yogyakarta 2012. 